\title{
Evaluation of the antidiarrheal activity of the leaf extracts of Myrtus communis Linn (Myrtaceae) in mice model
}

\author{
Mekonnen Sisay ${ }^{1}$, Ephrem Engidawork ${ }^{2}$ and Workineh Shibeshi ${ }^{2^{*}}$
}

\begin{abstract}
Background: Myrtus communis L. has a folkloric repute for the management of diarrhea and dysentery in different parts of the world. However, the safety and efficacy of the leaf extract have not been scientifically validated in animal model. This study was, therefore, aimed to investigate the antidiarrheal effect of $80 \%$ methanol extract (80ME) and solvent fractions of the leaves of Myrtus communis L. in mice.

Methods: The antidiarrheal activity of the $80 \mathrm{ME}$ and solvent fractions was evaluated against castor oil induced diarrheal model, charcoal meal and enteropooling tests. For the 80\%ME, the test groups received 100, 200 and $400 \mathrm{mg} / \mathrm{kg}$ of the extract. In case of fractions, the test groups received various doses of fractions (200, 300, $400 \mathrm{mg} / \mathrm{kg}$ and an additional dose of $800 \mathrm{mg} / \mathrm{kg}$ for the aqueous fraction (AF)), where as negative controls received the vehicle $(10 \mathrm{ml} / \mathrm{kg})$ and positive controls received loperamide $(3 \mathrm{mg} / \mathrm{kg}$ ).

Results: The $80 \mathrm{ME}$ at $200 \mathrm{mg} / \mathrm{kg}(p<0.05) \& 400 \mathrm{mg} / \mathrm{kg}(p<0.01)$ as well as the chloroform fraction (CF) and methanol fraction (MF) at $400 \mathrm{mg} / \mathrm{kg}(p<0.05)$ significantly delayed the onset of diarrhea. Besides, the 80ME (at all tested doses) and both of these fractions (at $300 \& 400 \mathrm{mg} / \mathrm{kg}$ ) significantly decreased the frequency and weight of fecal outputs. Results from the charcoal meal test revealed that the $80 \mathrm{ME}$, at all doses, $(p<0.001)$ as well as the CF and MF at $300 \mathrm{mg} / \mathrm{kg}(p<0.05) \& 400 \mathrm{mg} / \mathrm{kg}(p<0.001)$ produced a significant anti-motility effect. Similarly, in the entero-pooling test, the 80ME (at all tested doses) $(p<0.01$ ) as well as the CF and MF (at $300 \& 400 \mathrm{mg} / \mathrm{kg}, p<0.05$ ) produced a significant decline in the weight and volume of intestinal contents, whereas the AF revealed significant effect $(p<0.05)$ at dose of $800 \mathrm{mg} / \mathrm{kg}$ only.

Conclusion: The study demonstrated that the $80 \mathrm{ME}$ and solvent fractions contain bioactive constituents that have antidiarrheal activity. Therefore, this study provides a scientific support for the acclaimed traditional use of Myrtus communis $L$ for the treatment of diarrheal diseases.
\end{abstract}

Keywords: Myrtus communis, Castor oil, Antidiarrheal activity, 80\%ME, Solvent fractions

\section{Background}

Since the time immemorial, medicinal plants have played an invaluable role in the development of therapeutic agents. Currently, it is estimated that about $80 \%$ of people living in developing countries still rely on traditional medicine for their primary health care [1]. There are many medicinal plants that possess antidiarrheal activity with lesser side effects than the conventional

\footnotetext{
* Correspondence: shibeshiworkineh@gmail.com

${ }^{2}$ Department of Pharmacology and clinical Pharmacy, College of Health

Sciences, Addis Ababa University, Addis Ababa, Ethiopia

Full list of author information is available at the end of the article
}

drugs. Tannins, alkaloids, flavonoids and terpenoids are the major constituents that are primarily responsible for antidiarrheal activity of these medicinal herbs [2]. In Ethiopia, a range of medicinal plants have been widely used for the management of diarrhea and related gastrointestinal disorders by traditional healers [3-5]. However, the safety and therapeutic potentials of some of these medicinal plants have not been validated yet. Among them, Myrtus communis L. is one of the popular medicinal plants being used in the traditional medicine.

Myrtus communis L. (Myrtaceae) is the only species of the genus found in the Northern Hemisphere. It is an 
aromatic evergreen perennial shrub native to Southern Europe, North Africa and West Asia. Myrtus, the Greek name for Myrtle and communis means a common plant growing in groups [6-8]. In Ethiopia, it has several vernacular names such as Ades (Amharic, Guragegna, Tigregna); Haddus (hararegna), Addisaa, coddoo (Afan Oromo) [9]. It is one of the most important drugs being used in Unani system of medicine since ancient Greece. It is a well-known shrub for its therapeutic, cosmetic and food uses [8]. It has also been frequently used for various ailments like gastric ulcer, diarrhea, dysentery and rheumatism [8].

Moreover, the leaves of Myrtus communis L. are traditionally used for abdominal pain and diarrhea in Pakistanian and Indian traditional medicines [10], in Turkish traditional medicine (the leaves are boiled and the stock is drunk) [11] and in Iranian traditional medicine [12]. In Ethiopia, It has been used as antipyretic and sedative agent [13], anti-dandruff (bathing with crushed fresh leaves) [5], antidiarrheal and stomachic (the leaves are soaked with water overnight and the juice is taken orally in the morning) [5]. Previous in vitro study on isolated tissue preparations demonstrated that $70 \%$ methanolic extract of the leaves of Myrtus communis L. revealed antispasmodic, bronchodilator and vasodilator activities [14]. Besides, the essential oil of Myrtus communis L. (myrtle oil) also possessed significant antidiarrheal activity both in vivo and ex-vivo [15]. Therefore, extensive folkloric uses and previous studies were used as a baseline data to validate the antidiarrheal activity of the leaf extracts of Myrtus communis L. in mice.

\section{Methods}

\section{Drugs and chemicals}

All solvents used for the extraction process are of laboratory grade. Drugs and chemicals used in the study include: castor oil (Amman Pharmaceutical Industries, Jordan), activated charcoal (Acuro Organics Ltd, New Delhi, India), Loperamide (Daehwa Pharmaceuticals, Republic of Korea), distilled water (Ethiopian Pharmaceutical Manufacturing Factory, Epharm, Ethiopia), Tweens 80 (Atlas Chemical Industries Inc, India), chloroform (Hi-Media Laboratory Reagents, India), absolute methanol (Carlo Erba reagents, S.A.S., France), glacial acetic acid (BDH Laboratory Supplies Poole, England), sulfuric acid (BDH Laboratory Supplies Poole, England), ammonia(BDH Limited poole, England), hydrochloric acid(BDH Laboratory Supplies Poole, England), acetic anhydride (May and Baker LTD Dagenham, England), ferric chloride (BDH Laboratory Supplies Poole, England), Mayer's and Dragendorff's reagents(May and Baker LTD Dagenham, England).

\section{The plant material}

The leaves of Myrtus communis L. were collected from Mersa town, North Wollo zone, Amhara region (490 km northeast of Addis Ababa) in October, 2014. The plant was authenticated by a taxonomist and a voucher specimen (number MS 002) was deposited at the National Herbarium, College of Natural and Computational Sciences, Addis Ababa University (AAU) for future reference. The leaves were washed gently and dried at room temperature under shade for 2 weeks. The dried leaves were then reduced to appropriate size using mortar and pestle.

\section{Experimental animals}

Swiss albino mice of either sex weighing 20-30 g and aged 6-8 weeks were used for the experiment. The mice were obtained from animal house of School of Pharmacy, AAU and Ethiopian Public Health Institute (EPHI). The animals were kept in plastic cages at room temperature and on a $12 \mathrm{~h}$ light/dark cycle with access to pellet food and water ad libitum. The mice were acclimatized to laboratory condition for 1 week prior to the experiment. Food was withdrawn $18 \mathrm{~h}$ prior to the beginning of all the experiments. However, water was accessed except in entero-pooling, where both food and water were withdrawn. The care and handling was according to international guidelines for the use and maintenance of experimental animals $[16,17]$.

\section{Extraction of the plant material Preparation of $80 \mathrm{ME}$}

Hundred fifty gram of the dried powder was weighed using a digital balance and added to an Erlenmeyer flask to which $500 \mathrm{ml}$ of $80 \mathrm{ME}$ solvent was poured in the first round. The plant material was macerated for $72 \mathrm{~h}$ with occasional shaking using mini-orbital shaker (Bibby scientific limited stone Staffordshire, SI150SA, UK) at $120 \mathrm{rpm}$. The extract was filtered through double layered muslin cloth followed by Whatman No.1 filter paper (Schleicher and Schuell Micro science Gmbh, Germany). The marc was then re-macerated for a second and third time by adding another fresh solvent. The resultant filtrates were combined and concentrated using a rotary evaporator (Buchi labortechnik AG, Switzerland) under reduced pressure at $40{ }^{\circ} \mathrm{C}$. A dark green paste was obtained and kept into a deep freezer (AFTRON AFF 545, Denmark) to solidify. The residual aqueous solvent was then removed using a lyophilizer (Operon, Korea vacuum limited, Korea). The percentage yield of $80 \mathrm{ME}$ was then found to be $16.33 \%(\mathrm{w} / \mathrm{w})$. Finally, the extract was kept in deep freeze with an air tight container until the experiment. 


\section{Preparation of solvent fractions}

Both Soxhlet and maceration techniques were used for extraction of the plant material. The initial procedure closely resembles to that of the 80ME. However, the dried leaves were pulverized to coarse powder using mortar and pestle and then sieved to maintain uniformity of particle size. From this, $150 \mathrm{~g}$ dry powder was subjected to successive soxhlet extraction with solvents of increasing polarity (chloroform and absolute methanol) followed by maceration of the marc of methanol with distilled water.

In every batch, $50 \mathrm{~g}$ of the powdered plant material was added into the extraction thimble which was then placed into the chamber of the Soxhlet apparatus. First, $350 \mathrm{ml}$ chloroform was added into the bottom flask that had been fixed with Soxhlet apparatus and heat was applied until clear liquid contents of the chamber siphoned into the solvent. The CF was then subjected to filtration with suction filter. Besides, it was concentrated using rotary evaporator under reduced pressure set at $40{ }^{\circ} \mathrm{C}$ followed by dried with oven at room temperature for $48 \mathrm{~h}$. The marc (in the thimble) was collected and then dried overnight at room temperature to remove chloroform. The dried marc was re-extracted using absolute methanol using the same procedure as described for the CF except that the MF was kept for a week in an oven at room temperature. Besides, the marc of MF was then collected and dried at room temperature overnight. Finally, the dried marc of methanol was combined from every batch and macerated in an Erlenmeyer flask with distilled water and allowed to stand at room temperature for a period of 3 days in each round (total of 9 days) with occasional shaking using miniorbital shaker. The procedure utilized for extraction of $80 \mathrm{ME}$ was repeated except that lyophilization instead of vaporization was used directly to concentrate the extract. After drying, the percentage yields of all fractions were determined and found to be 5.2, 13.8 and $7.2 \%$ for the CF, MF and AF, respectively. The fractions were kept in deep freeze with air tight containers till use.

\section{Acute oral toxicity test}

According to the Organization for Economic Cooperation and Development (OECD) guidelines 2008: 425, a single female mouse was fasted for $3 \mathrm{~h}$ and was loaded with $2000 \mathrm{mg} / \mathrm{kg}$ of the $80 \mathrm{ME}$ as a single dose by oral gavage. It was then observed for any sign of toxicity within the first $24 \mathrm{~h}$. Based on the results of the first mouse; another 4 female mice were recruited and fasted for $3 \mathrm{~h}$. Thereafter, they were given the same dose and observed for any sign of toxicity or death in the next 14 days [18].

\section{Grouping and dosing}

Mice were randomly assigned into five groups of six animals each for both $80 \mathrm{ME}$ and solvent fractions. All groups received their respective treatments using oral gavage. The first group was assigned as negative control and received a vehicle (distilled water for $80 \mathrm{ME}$, MF and $\mathrm{AF}$ and $2 \%$ tweens- 80 for the $\mathrm{CF}$ ) at $10 \mathrm{ml} / \mathrm{kg}$. The second group was assigned as positive control and received the standard drug, loperamide $(3 \mathrm{mg} / \mathrm{kg})$. For the $80 \mathrm{ME}$, the dose levels of test groups were determined based on the acute toxicity test [18] and they are treated with $100 \mathrm{mg} / \mathrm{kg}, 200 \mathrm{mg} / \mathrm{kg}$ and $400 \mathrm{mg} / \mathrm{kg}$ of $80 \mathrm{ME}$. Coming to the solvent fractions, however, the doses of test groups were determined based on series of pilot studies and hence test groups were treated with various doses of the fractions $(200 \mathrm{mg} / \mathrm{kg}, 300 \mathrm{mg} / \mathrm{kg}$ and $400 \mathrm{mg} / \mathrm{kg}$ and an additional dose of $800 \mathrm{mg} / \mathrm{kg}$ for the $\mathrm{AF})$. The $80 \mathrm{ME}$ and solvent fractions were reconstituted with the respective vehicles at appropriate concentrations. The solutions were prepared fresh on the day of the experiments.

\section{Determination of antidiarrheal activity Castor oil (CO) induced diarrhea}

The method followed by Umer et al. was used for this study [19]. Swiss albino mice of either sex were fasted for $18 \mathrm{~h}$, randomly allocated to five groups of six animals each and treated as described previously. One hour after administration of the respective doses and treatments, all animals received $0.5 \mathrm{ml}$ of $\mathrm{CO}$. Thereafter, they were individually placed in cages where the floor was lined with white paper. During an observation period of $4 \mathrm{~h}$, the onset of diarrhea, frequency of defecation and the weight of fecal output (wet and total feces in gram) were recorded for individual mouse. The percentages of diarrheal inhibition and weight of fecal output were determined according to the formulae 1-3 [20, 21].

$\%$ of inhibition $=\frac{\text { Average number of WFC-Average number of WFT }}{\text { Average number of WFC }} \times 100$

Where, WFC = wet feces in the control; WFT = wet feces in the test group.

Percentage of wetfecal output $=\frac{\text { Mean weight of wetfeces of each group }}{\text { Mean weight of wet feces of control }} \times 100$

Percentage of totalfecal output $=\frac{\text { Mean weight of total feces of each group }}{\text { Mean weight of total feces of control }} \times 100$

\section{CO induced gastrointestinal motility}

All mice were fasted for $18 \mathrm{~h}$, divided into five groups of six animals each and treated as described earlier. An 
hour later, $0.5 \mathrm{ml} \mathrm{CO}$ was administered. Then, $1 \mathrm{ml}$ of marker $(5 \%$ activated charcoal suspension in distilled water) was administered orally $1 \mathrm{~h}$ after $\mathrm{CO}$ treatment. The animals were then sacrificed after an hour and the small intestine was dissected out from pylorus to cecum. The distance travelled by the charcoal meal from the pylorus was measured and expressed as percentage of the total length of the small intestine from the pylorus to cecum (peristaltic index) as shown in formula 4. The percentage of inhibition was then expressed using the formula 5 [22].

$$
\text { Peristaltic index }(P I)=\frac{\text { distance travelled by charcoal meal }}{\text { whole length of small intestine }} \times 100
$$

$$
\% \text { inhibition }=\frac{\text { PIC-PIT }}{\text { PIC }} \times 100
$$

Where, PIC $=$ peristaltic index of control; PIT $=$ peristal tic index of test group

\section{CO induced enteropooling activity}

Intraluminal fluid accumulation was determined using the method described by Islam et al. [23]. Mice of either sex were deprived of both food and water for $18 \mathrm{~h}$ and treated as described in grouping and dosing section just one hour prior to oral administration of $0.5 \mathrm{ml} \mathrm{CO}$. An hour after $\mathrm{CO}$ administration, the mice were sacrificed by cervical dislocation. The abdomen of each mouse was opened; the small intestine was then taken from the pyloric sphincter to ileo-caecal junction; ligated at both ends and dissected out carefully. Each small intestine was weighed and its content was then collected by gentle milking into a graduated tube and hence the volume of intestinal contents was measured. Each intestine was reweighed and the difference between the full and the empty intestines was calculated. Eventually, the percentage inhibitions of the volume and weight of intestinal contents were determined according to the formulae 6 and 7 , respectively [24].

$$
\text { Percentage of inhibition }=\frac{\text { MVICC }- \text { MVICT }}{\text { MVICC }} X 100
$$

Where, MVICC $=$ Mean volume of the intestinal content of the control group; MVICT = Mean volume of the intestinal content of the test group.

$$
\text { Percentage of inhibition }=\frac{\text { MWICC }- \text { MWICT }}{\text { MWICC }} X 100
$$

Where, MWICC $=$ Mean weight of the intestinal content of the control group; MWICT = Mean weight of the intestinal content of the test group.
The in vivo anti-diarrheal index

The in vivo antidiarrheal index (ADI) for the 80ME, solvent fractions and standard drug were determined by the following formula [25].

In vivo anti diarrheal index $(A D I)=\sqrt[3]{\text { Dfreq } x \text { Gmeq } x \text { Pfreq }}$

Where: Dfreq = Delay in defecation time or diarrheal onset (in \% of control); Gmeq = Gut meal travel reduction (in \% of control) and Pfreq = purging frequency as the number of wet stool reduction (in \% of control).

\section{Preliminary phytochemical screening}

The 80ME and solvent fractions were tested for the presence of alkaloids, flavonoids, tannins, terpenoids, steroids, glycosides and saponines using standard chemical tests [26].

\section{Statistical analysis}

Data are expressed as mean \pm standard error of the mean (SEM). The data were analyzed using SPSS version 16 . Statistical significance was determined by one way analysis of variance (ANOVA) followed by Tukey post Hoc test. $P$-value of less than 0.05 was considered statistically significant. When appropriate, linear regression analysis was also applied to observe the dose dependency nature of antidiarrheal effect.

\section{Results}

\section{Acute oral toxicity test}

The 80ME of Myrtus communis leaf produced neither overt toxicity nor death during the 14 days observation period following oral administration of a single dose of $2000 \mathrm{mg} / \mathrm{kg}$. The absence of mortality and signs of overt toxicity up to 5 times the maximum effective dose of the extract suggested that $80 \mathrm{ME}$ has a wider safety margin and $\mathrm{LD}_{50}$ value greater than $2000 \mathrm{mg} / \mathrm{kg}$ in mice.

\section{Effects on castor oil induced diarrheal model}

In the CO-induced diarrheal model, the 80ME of Myrtus communis leaf significantly prolonged the onset of diarrhea and reduced the frequency and weight of fecal outputs at doses of $200 \mathrm{mg} / \mathrm{kg}$ and $400 \mathrm{mg} / \mathrm{kg}$ as compared to the control. The $100 \mathrm{mg} / \mathrm{kg}$ of the extract, however, showed a statistically significant effect on frequency of wet feces $(p<0.001)$, weight of wet $(p<0.001)$ and total $(p<0.05)$ fecal outputs. Besides, the data revealed that the percentage of diarrheal inhibitions were $42.58 \%(p<$ $0.01), 62.52 \%(p<0.001)$, and $74.96 \%(p<0.001)$ at the doses of $100 \mathrm{mg} / \mathrm{kg}, 200 \mathrm{mg} / \mathrm{kg}$, and $400 \mathrm{mg} / \mathrm{kg}$, respectively (Table 1).

Coming to solvent fractions, both CF and MF produced a significant delay in initiation of diarrhea at $400 \mathrm{mg} / \mathrm{kg} \quad(p<0.05)$. The percentage of diarrheal 
Table 1 Antidiarrheal effects of 80ME and solvent fractions of the leaves of Myrtus communis Linn on castor oil induced diarrheal model in mice

\begin{tabular}{|c|c|c|c|c|c|c|c|c|}
\hline $\begin{array}{l}\text { Dose } \\
(\mathrm{mg} / \mathrm{kg})\end{array}$ & $\begin{array}{l}\text { Onset of diarrhea } \\
\text { (Min) }\end{array}$ & No of wet feces & $\begin{array}{l}\text { Total No } \\
\text { of feces }\end{array}$ & $\begin{array}{l}\text { Average weight of } \\
\text { wet feces }(\mathrm{gm})\end{array}$ & $\begin{array}{l}\text { Average weight } \\
\text { of total feces ( } \mathrm{gm} \text { ) }\end{array}$ & $\begin{array}{l}\% \text { inhibition of } \\
\text { defecation }\end{array}$ & $\begin{array}{l}\% \\
\text { WWFO }\end{array}$ & $\begin{array}{l}\% \\
\text { WTFO }\end{array}$ \\
\hline Control & $76.67 \pm 7.99$ & $6.67 \pm 0.49$ & $7.00 \pm 0.52$ & $0.36 \pm 0.02$ & $0.37 \pm 0.02$ & -———- & -—- & - \\
\hline 80ME 100 & $109.67 \pm 12.15$ & $3.83 \pm 0.70^{\mathrm{a} 2 \mathrm{~b} 1 \mathrm{f} 1}$ & $4.50 \pm 0.72^{\mathrm{b} 1 f 1}$ & $0.20 \pm 0.02^{\mathrm{a} 2 \mathrm{~b} 2 \mathrm{f} 2}$ & $0.21 \pm 0.02^{\mathrm{a} 1 \mathrm{~b} 1 \mathrm{f} 1}$ & 42.58 & 55.56 & 56.76 \\
\hline 80ME 200 & $145.00 \pm 21.77^{\mathrm{a} 1}$ & $2.50 \pm 0.50^{\mathrm{a} 3}$ & $3.00 \pm 0.68^{\mathrm{a} 2}$ & $0.14 \pm 0.03^{\mathrm{a} 3}$ & $0.15 \pm 0.03^{\mathrm{a} 2}$ & 62.52 & 38.89 & 40.54 \\
\hline 80ME 400 & $173.83 \pm 18.03^{\mathrm{a} 2}$ & $1.67 \pm 0.49^{\mathrm{a} 3}$ & $2.67 \pm 0.72^{\mathrm{a} 2}$ & $0.08 \pm 0.02^{\mathrm{a} 3}$ & $0.10 \pm 0.03^{\mathrm{a} 3}$ & 74.96 & 22.22 & 27.03 \\
\hline Loperamide 3 & $161.50 \pm 16.93^{\mathrm{a} 2}$ & $1.83 \pm 0.40^{a 3}$ & $2.83 \pm 0.60^{a 2}$ & $0.09 \pm 0.02^{\mathrm{a3}}$ & $0.11 \pm 0.02^{\mathrm{a} 3}$ & 72.56 & 25.00 & 29.73 \\
\hline Control & $80.17 \pm 4.34$ & $6.50 \pm 0.43$ & $6.83 \pm 0.54$ & $0.35 \pm 0.03$ & $0.36 \pm 0.04$ & - - & -—- & - - \\
\hline CF 200 & $123.33 \pm 23.81$ & $4.00 \pm 1.00$ & $4.33 \pm 1.08$ & $0.20 \pm 0.05$ & $0.21 \pm 0.06$ & 38.46 & 57.14 & 58.33 \\
\hline CF 300 & $140.50 \pm 19.99$ & $3.17 \pm 0.65^{\mathrm{a} 1}$ & $3.67 \pm 0.76$ & $0.16 \pm 0.03^{\mathrm{a} 1}$ & $0.17 \pm 0.04^{\mathrm{a} 1}$ & 51.23 & 45.71 & 47.22 \\
\hline CF 400 & $152.00 \pm 21.01^{\mathrm{a} 1}$ & $2.67 \pm 0.76^{\mathrm{a} 1}$ & $3.17 \pm 0.83^{\mathrm{a} 1}$ & $0.13 \pm 0.04^{\mathrm{a} 1}$ & $0.15 \pm 0.04^{\mathrm{a} 1}$ & 58.92 & 37.14 & 41.67 \\
\hline Loperamide 3 & $165.83 \pm 33.17^{\mathrm{a} 1}$ & $1.67 \pm 0.76^{\mathrm{a} 2}$ & $2.33 \pm 1.05^{\mathrm{a} 1}$ & $0.08 \pm 0.04^{\mathrm{a} 2}$ & $0.09 \pm 0.04^{\mathrm{a} 2}$ & 74.31 & 22.86 & 25.00 \\
\hline Control & $69.33 \pm 8.98$ & $7.50 \pm 1.34$ & $8.17 \pm 1.28$ & $0.42 \pm 0.05$ & $0.45 \pm 0.05$ & 一一 & 一一 & - \\
\hline MF 200 & $104.33 \pm 6.14$ & $5.17 \pm 0.40^{\mathrm{b} 1}$ & $5.67 \pm 0.49^{\mathrm{b} 1}$ & $0.29 \pm 0.03^{\mathrm{b} 1}$ & $0.30 \pm 0.04^{\mathrm{b} 1}$ & 31.07 & 69.05 & 66.67 \\
\hline MF 300 & $136.00 \pm 29.02$ & $3.83 \pm 0.87^{\mathrm{a} 1}$ & $4.33 \pm 1.05$ & $0.22 \pm 0.06^{\mathrm{a} 1}$ & $0.24 \pm 0.06^{\mathrm{a} 1}$ & 48.93 & 52.38 & 53.33 \\
\hline MF 400 & $155.50 \pm 26.89^{\mathrm{a} 1}$ & $2.83 \pm 0.95^{\mathrm{a} 1}$ & $3.50 \pm 1.23^{\mathrm{a} 1}$ & $0.14 \pm 0.06^{\mathrm{a} 2}$ & $0.17 \pm 0.06^{\mathrm{a} 2}$ & 62.67 & 33.33 & 37.78 \\
\hline Loperamide 3 & $166.83 \pm 25.23^{\mathrm{a} 1}$ & $1.83 \pm 0.70^{\mathrm{a} 2}$ & $2.33 \pm 0.92^{\mathrm{a} 2}$ & $0.09 \pm 0.03^{\mathrm{a} 3}$ & $0.11 \pm 0.04^{\mathrm{a} 3}$ & 75.56 & 21.43 & 24.44 \\
\hline Control & $69.33 \pm 8.98$ & $7.50 \pm 1.34$ & $8.17 \pm 1.28$ & $0.42 \pm 0.05$ & $0.45 \pm 0.05$ & -—— & - - & - \\
\hline AF 200 & $70.83 \pm 6.53^{\mathrm{b} 2 \mathrm{j} 1 \mathrm{n} 1}$ & $6.83 \pm 0.70^{\mathrm{b} 2 i 1 \mathrm{j} 1 \mathrm{~m} \ln 1}$ & $7.67 \pm 0.67^{b 2 g 111 j 1 \mathrm{n} 1}$ & $0.39 \pm 0.02^{\mathrm{b} 3 g 2 i 2 j 2 \mathrm{n} 2}$ & $0.42 \pm 0.02^{\mathrm{b} 3 \mathrm{~g} 2 \mathrm{i} j \mathrm{j} 2 \mathrm{n} 2}$ & 8.93 & 92.86 & 93.33 \\
\hline AF 300 & $77.67 \pm 4.86^{\mathrm{b} 1 \mathrm{j} 1 \mathrm{n} 1}$ & $6.33 \pm 0.72^{\mathrm{b2j} 1 \mathrm{n} 1}$ & $6.67 \pm 0.76^{\mathrm{b} 1 \mathrm{j} \mid \mathrm{n} 1}$ & $0.35 \pm 0.03^{\mathrm{b} 2 g^{1 i 1 j / n 1}}$ & $0.36 \pm 0.04^{b 2 i 1 j 1 n 1}$ & 15.60 & 83.33 & 80.00 \\
\hline AF 400 & $81.00 \pm 3.53^{b 1}$ & $5.67 \pm 0.62^{\mathrm{b} 1 \mathrm{j} 1 \mathrm{n} 1}$ & $6.50 \pm 0.62^{b 1 j 1}$ & $0.32 \pm 0.02^{\mathrm{b} 2 \mathrm{j} 1 \mathrm{n} 1}$ & $0.33 \pm 0.02^{\mathrm{b} 1 \mathrm{j} 1 \mathrm{n} 1}$ & 24.40 & 76.19 & 73.33 \\
\hline AF 800 & $134.67 \pm 32.67$ & $3.50 \pm 0.99^{\mathrm{a} 1}$ & $4.33 \pm 1.22^{\mathrm{a} 1}$ & $0.18 \pm 0.05^{\mathrm{a} 2}$ & $0.21 \pm 0.05^{\mathrm{a} 2}$ & 53.33 & 42.86 & 46.67 \\
\hline Loperamide 3 & $166.83 \pm 25.23^{\mathrm{a} 1}$ & $1.83 \pm 0.70^{\mathrm{a} 2}$ & $2.33 \pm 0.92^{\mathrm{a} 2}$ & $0.09 \pm 0.03^{\mathrm{a} 3}$ & $0.11 \pm 0.04^{\mathrm{a} 3}$ & 75.56 & 21.43 & 24.44 \\
\hline
\end{tabular}

Values are mean \pm SEM $(n=6)$; analysis was performed using one way ANOVA followed by Tuckey post hoc test; ${ }^{a}$ compared with control values; ${ }^{b}$ compared with loperamide; ${ }^{\mathrm{c}}$ compared with $100 \mathrm{mg} / \mathrm{kg} ;{ }^{\mathrm{d}}$ compared with $200 \mathrm{mg} / \mathrm{kg} ;{ }^{\mathrm{e}}{ }^{\mathrm{comp}}$ cored with $300 \mathrm{mg} / \mathrm{kg} ;{ }^{\mathrm{f}}$ compared with $400 \mathrm{mg} / \mathrm{kg} ;{ }^{\mathrm{g}} \mathrm{compared}$ with $800 \mathrm{mg} / \mathrm{kg} ;{ }^{\mathrm{h}}$ compared with CF200; ${ }^{i}$ compared with CF300; ${ }^{j}$ compared with CF400; ${ }^{\mathrm{k}}$ compared with MF200; ${ }^{\mathrm{m}}$ compared with MF 300; ${ }^{\mathrm{n}}$ compared with MF $400 ;{ }^{1} p<0.05,{ }^{2} p<$ $0.01,{ }^{3} p<0.001 ; 80 \mathrm{ME}=80 \%$ methanol extract, $\mathrm{CF}=$ chloroform fraction, $\mathrm{MF}=$ methanol fraction, $\mathrm{AF}=$ aqueous fraction. Controls received $10 \mathrm{ml} / \mathrm{kg}-\mathrm{distilled}$ water (for $80 \mathrm{ME}, \mathrm{MF}$ and $\mathrm{AF}$ ) and $2 \%$ Tween-80 (for CF). WWFO = Weight of wet fecal output, WTFO = weight of total fecal output

inhibitions obtained as compared to control were $51.23 \%(p<0.05)$ and $58.92 \%(p<0.05)$ at $300 \mathrm{mg} / \mathrm{kg}$ and $400 \mathrm{mg} / \mathrm{kg} \mathrm{CF}$, respectively. The CF also showed a significant reduction in weight of both wet and total fecal outputs at $300 \mathrm{mg} / \mathrm{kg}(p<0.05)$ and $400 \mathrm{mg} / \mathrm{kg}$ $(p<0.05)$. Similarly, the MF significantly decreased the frequency and weight of wet feces at doses of $300 \mathrm{mg} / \mathrm{kg}(p<0.05 ; \mathrm{p}<0.05)$ and $400 \mathrm{mg} / \mathrm{kg}(p<$ $0.05 ; p<0.01)$, respectively with the highest percentage of diarrheal inhibition $(62.67 \%, p<0.05)$ obtained at $400 \mathrm{mg} / \mathrm{kg}$. On the contrary, the AF was devoid of any significant delay in onset of diarrhea at all tested doses as compared with control (Table 1).

There was a dose-dependent reduction in the percentage of weight of wet and total fecal outputs in $80 \mathrm{ME}$ and solvent fractions with $400 \mathrm{mg} / \mathrm{kg}$ of the 80ME displaying the highest effect (22.22 and 27.03\%). Besides, both the CF and MF revealed a moderate reduction in the percentage of both fecal outputs with $400 \mathrm{mg} / \mathrm{kg}$ MF showing the utmost effect among the solvent fractions (Table 1).

\section{Effects on castor oil induced intestinal transit in mice}

The $80 \mathrm{ME}$ significantly inhibited the intestinal transit of charcoal meal at all tested doses. The data revealed that the percentage reduction of gastrointestinal transit of charcoal was $33.54 \%(p<0.001), 46.12 \%(p<0.001)$, and $62.31 \%(p<0.001)$ at doses of $100 \mathrm{mg} / \mathrm{kg}, 200 \mathrm{mg} / \mathrm{kg}$, and $400 \mathrm{mg} / \mathrm{kg}$, respectively. The maximum dose of this extract showed comparable anti-motility effects to that of the standard $(59.61 \%, p<0.001)$.

The CF and MF also significantly inhibited the intestinal transit of charcoal meal at doses of $300 \mathrm{mg} / \mathrm{kg}$ and $400 \mathrm{mg} / \mathrm{kg}$ compared to the control with the highest inhibitory effect observed at later dose of MF $(47.54 \%, p<$ 0.001). On the contrary, the AF showed a significant antimotility effect at the dose of $800 \mathrm{mg} / \mathrm{kg}(38.61 \%, p<$ 0.01) compared to the control (Table 2).

\section{Effects on castor oil induced enteropooling}

In this test, the $80 \mathrm{ME}$ showed a significant reduction in both the average volume and weight of intestinal contents (AVIC and AWIC) at all tested doses as compared 
Table 2 Effects of 80ME and solvent fractions of the leaves of Myrtus communis $L$ on gastrointestinal transit in mice

\begin{tabular}{|c|c|c|c|c|}
\hline Dose (mg/kg) & $\begin{array}{l}\text { Length of small } \\
\text { intestine }(\mathrm{cm})\end{array}$ & $\begin{array}{l}\text { Distance moved by the } \\
\text { charcoal meal }(\mathrm{cm})\end{array}$ & Peristaltic index (\%) & $\%$ inhibition \\
\hline Control & $56.17 \pm 1.42$ & $36.67 \pm 1.94$ & $65.09 \pm 2.25$ & 一一一一 \\
\hline 80ME 100 & $58.33 \pm 0.80$ & $25.17 \pm 2.43^{\mathrm{a} 3 \mathrm{~b} 2 f 2}$ & $43.26 \pm 4.37^{\mathrm{a} 3 \mathrm{~b} 2 f 2}$ & 33.54 \\
\hline 80ME 200 & $58.67 \pm 1.12$ & $20.05 \pm 1.09^{\mathrm{a} 3}$ & $35.07 \pm 2.27^{\mathrm{a} 3}$ & 46.12 \\
\hline 80ME 400 & $58.17 \pm 2.01$ & $14.33 \pm 1.65^{\mathrm{a} 3}$ & $24.53 \pm 2.53^{\mathrm{a} 3}$ & 62.31 \\
\hline Loperamide 3 & $56.33 \pm 1.28$ & $14.83 \pm 0.91^{\mathrm{a} 3}$ & $26.29 \pm 1.34^{\mathrm{a} 3}$ & 59.61 \\
\hline Control & $57.67 \pm 1.76$ & $36.17 \pm 4.18$ & $62.33 \pm 6.06$ & -——- \\
\hline CF 200 & $56.33 \pm 1.08$ & $25.17 \pm 3.46^{b 1}$ & $44.88 \pm 6.39^{\mathrm{b} 1}$ & 27.99 \\
\hline CF 300 & $59.50 \pm 1.09$ & $24.00 \pm 1.39^{\mathrm{a} 1}$ & $40.44 \pm 2.60^{\mathrm{a} 1}$ & 35.11 \\
\hline CF 400 & $60.17 \pm 1.89$ & $20.67 \pm 2.43^{\mathrm{a} 2}$ & $34.37 \pm 3.91^{\mathrm{a} 2}$ & 44.86 \\
\hline Loperamide 3 & $56.83 \pm 1.11$ & $14.00 \pm 1.41^{\mathrm{a} 3}$ & $24.58 \pm 2.32^{\mathrm{a} 3}$ & 60.56 \\
\hline Control & $58.50 \pm 0.67$ & $36.83 \pm 3.21$ & $62.81 \pm 5.11$ & —— \\
\hline MF 200 & $59.17 \pm 1.38$ & $29.17 \pm 1.96^{\mathrm{b} 2}$ & $49.47 \pm 3.47^{\mathrm{b} 2}$ & 21.24 \\
\hline MF 300 & $59.50 \pm 1.41$ & $24.00 \pm 3.33^{\mathrm{a} 1}$ & $40.29 \pm 5.48^{\mathrm{a} 1}$ & 35.85 \\
\hline MF 400 & $59.00 \pm 1.59$ & $19.17 \pm 3.27^{\mathrm{a} 3}$ & $32.95 \pm 5.99^{\mathrm{a} 3}$ & 47.54 \\
\hline Loperamide 3 & $56.33 \pm 1.28$ & $13.67 \pm 1.52^{\mathrm{a} 3}$ & $24.20 \pm 2.55^{\mathrm{a} 3}$ & 61.47 \\
\hline Control & $58.50 \pm 0.67$ & $36.83 \pm 3.21$ & $62.81 \pm 5.11$ & -—- \\
\hline AF 200 & $56.83 \pm 0.95$ & $34.00 \pm 1.83^{\mathrm{b} 3 \mathrm{~g} 1 \mathrm{j} 1 \mathrm{n} 1}$ & $59.79 \pm 2.98^{\mathrm{b} 3 g 1 j \mathrm{ln} 2}$ & 4.81 \\
\hline AF 300 & $56.83 \pm 1.92$ & $31.00 \pm 2.05^{\mathrm{b} 2 \mathrm{~g} 1}$ & $54.91 \pm 4.33^{\mathrm{b} 2 \mathrm{~g} 1 \mathrm{n} 1}$ & 12.58 \\
\hline AF 400 & $59.17 \pm 0.98$ & $29.50 \pm 3.09^{\mathrm{b} 2}$ & $49.79 \pm 4.95^{\mathrm{b} 2}$ & 20.73 \\
\hline AF 800 & $56.83 \pm 1.17$ & $21.83 \pm 3.55^{\mathrm{a} 2}$ & $38.56 \pm 6.29^{\mathrm{a} 2}$ & 38.61 \\
\hline Loperamide 3 & $56.33 \pm 1.28$ & $13.67 \pm 1.52^{\mathrm{a} 3}$ & $24.20 \pm 2.55^{\mathrm{a} 3}$ & 61.47 \\
\hline
\end{tabular}

Values are mean \pm SEM $(n=6)$; analysis was performed using one way ANOVA followed by Tuckey post hoc test; ${ }^{\text {a }}$ compared with control values; ${ }^{\mathrm{b}}$ compared with loperamide; ${ }^{\mathrm{C}}$ compared with $100 \mathrm{mg} / \mathrm{kg} ;{ }^{\mathrm{d}}$ compared with $200 \mathrm{mg} / \mathrm{kg} ;{ }^{\mathrm{e}}$ compared with $300 \mathrm{mg} / \mathrm{kg} ;{ }^{\mathrm{f}}$ compared with $400 \mathrm{mg} / \mathrm{kg} ;{ }^{\mathrm{g}}$ compared with $800 \mathrm{mg} / \mathrm{kg} ;{ }^{\mathrm{h}}$ compared with CF200; ${ }^{i}$ compared with CF300; ${ }^{j}$ compared with CF400; ${ }^{k}$ compared with MF200; ${ }^{m}$ compared with MF 300; ${ }^{n}$ compared with MF 400; ${ }^{1} p<0.05$, ${ }^{2} p<0.01,{ }^{3} p<0.001 ; 80 \mathrm{ME}=80 \%$ methanol extract, $\mathrm{CF}=$ chloroform fraction, MF = methanol fraction, $\mathrm{AF}=$ aqueous fraction. Controls received $10 \mathrm{ml} / \mathrm{kg}$ - distilled water (for $80 \mathrm{ME}, \mathrm{MF}$ and $\mathrm{AF}$ ) and $2 \%$ Tween-80 (for CF)

to control. The percentage inhibition of volume of intestinal contents was found to be $25.58 \%(p<0.01), 38.37 \%$ $(p<0.001)$, and $46.51 \%(p<0.001)$ at doses of $100 \mathrm{mg} /$ $\mathrm{kg}, 200 \mathrm{mg} / \mathrm{kg}, 400 \mathrm{mg} / \mathrm{kg}$, respectively.

The CF and MF reduced both AVIC and AWIC significantly at doses of $300 \mathrm{mg} / \mathrm{kg}$ and $400 \mathrm{mg} / \mathrm{kg}$. Maximal inhibition of the AVIC was observed at $400 \mathrm{mg} / \mathrm{kg}$, being $38.46 \%(p<0.01)$ and $40.96 \%(p<0.01)$ for CF and MF, respectively. On the contrary, the AF was devoid of any significant inhibitory effect on the AVIC and AWIC up to $400 \mathrm{mg} / \mathrm{kg}$ as compared to control (Table 3).

\section{The in vivo antidiarrheal index}

The in vivo antidiarrheal index (ADI) was measured by considering the delay in defecation (time of onset, Dfreq), gut meal travel distance (Gmeq) and purging frequency in number of wet stools as major parameters. The greatest ADI was achieved at the dose of $400 \mathrm{mg} / \mathrm{kg}$ of $80 \mathrm{ME}$ (83.96\%). Among the solvent fractions, MF showed the highest ADI value (71.81\%) at doses of $400 \mathrm{mg} / \mathrm{kg}$ (Table 4).

\section{Preliminary phytochemical screening}

The preliminary phytochemical screening of the $80 \mathrm{ME}$ of Myrtus communis leaf revealed the presence of terpenoids, flavonoids, tannins, glycosides and saponins but alkaloids and steroids are lacking. Coming to the solvent fractions, the data revealed that alkaloids were not detected in all solvent fractions and trace amounts of steroids were detected in the CF. Besides, terpenoids and flavonoids were detected in both CF and MF. Tannins were common across all fractions. Glycosides and saponins were also observed in both MF and AF. Amongst all, the $80 \mathrm{ME}$ and the MF appeared to be relatively rich in secondary metabolites (Table 5).

\section{Discussion}

Medicinal plants have been used for the treatment of various disorders including diarrhea and related gastrointestinal disorders despite the fact that their safety and efficacy profiles have not been well addressed. It is, therefore, important to properly evaluate the safety and efficacy profile of medicinal plants that are being used in traditional medicines. The need for newer, more 
Table 3 Effects of 80ME and solvent fractions of the leaves of Myrtus communis $L$ on gastrointestinal fluid accumulation in mice

\begin{tabular}{|c|c|c|c|c|}
\hline Dose (mg/kg) & Volume of intestinal contents (ml) & $\%$ inhibition & Weight of intestinal contents (gm) & \% inhibition \\
\hline Control & $0.86 \pm 0.07$ & -—-—- & $1.12 \pm 0.03$ & -—-—— \\
\hline 80ME 100 & $0.64 \pm 0.04^{\mathrm{a} 2 \mathrm{~b} 1 \mathrm{f} 1}$ & 25.58 & $0.91 \pm 0.05^{\mathrm{a} 2 \mathrm{~b} 1 \mathrm{f} 1}$ & 18.75 \\
\hline 80ME 200 & $0.53 \pm 0.03^{\mathrm{a} 3}$ & 38.37 & $0.77 \pm 0.06^{\mathrm{a} 3}$ & 31.25 \\
\hline 80ME 400 & $0.46 \pm 0.02^{\mathrm{a} 3}$ & 46.51 & $0.70 \pm 0.02^{\mathrm{a} 3}$ & 37.50 \\
\hline Loperamide 3 & $0.47 \pm 0.04^{\mathrm{a} 3}$ & 45.35 & $0.71 \pm 0.03^{\mathrm{a} 3}$ & 36.61 \\
\hline Control & $0.78 \pm 0.08$ & 一一一一- & $1.02 \pm 0.07$ & -———- \\
\hline CF 200 & $0.61 \pm 0.07^{\mathrm{b} 1}$ & 21.79 & $0.85 \pm 0.07^{\mathrm{b} 1}$ & 16.67 \\
\hline CF 300 & $0.53 \pm 0.04^{\mathrm{a} 1}$ & 32.05 & $0.75 \pm 0.04^{\mathrm{a} 1}$ & 26.47 \\
\hline CF 400 & $0.48 \pm 0.04^{\mathrm{a} 2}$ & 38.46 & $0.69 \pm 0.03^{\mathrm{a} 2}$ & 32.35 \\
\hline Loperamide 3 & $0.43 \pm 0.06^{\mathrm{a} 2}$ & 44.87 & $0.66 \pm 0.05^{\mathrm{a} 3}$ & 35.29 \\
\hline Control & $0.83 \pm 0.06$ & -—- & $1.10 \pm 0.03$ & -—-—— \\
\hline MF 200 & $0.67 \pm 0.04^{\mathrm{b} 1}$ & 19.28 & $0.93 \pm 0.07^{\mathrm{b} 1}$ & 15.45 \\
\hline MF 300 & $0.58 \pm 0.03^{\mathrm{a} 1}$ & 30.12 & $0.81 \pm 0.04^{\mathrm{a} 1}$ & 26.36 \\
\hline MF 400 & $0.49 \pm 0.08^{\mathrm{a} 2}$ & 40.96 & $0.73 \pm 0.08^{\mathrm{a} 2}$ & 33.64 \\
\hline Loperamide 3 & $0.47 \pm 0.04^{\mathrm{a} 3}$ & 43.47 & $0.68 \pm 0.02^{\mathrm{a} 3}$ & 38.18 \\
\hline Control & $0.83 \pm 0.06$ & - - - & $1.10 \pm 0.03$ & -—-—— \\
\hline AF 200 & $0.76 \pm 0.04^{\mathrm{b} 2 \mathrm{~g} 1 \mathrm{j} 1 \mathrm{n} 1}$ & 8.43 & $1.02 \pm 0.05^{\mathrm{b} 3 \mathrm{~g} 2 \mathrm{j} 2 \mathrm{n} 1}$ & 8.18 \\
\hline AF 300 & $0.73 \pm 0.07^{\mathrm{b} 1 \mathrm{j} 1 \mathrm{n} 1}$ & 12.05 & $0.98 \pm 0.07^{\mathrm{b} 2 \mathrm{~g} 1 \mathrm{j} 1}$ & 10.91 \\
\hline AF 400 & $0.68 \pm 0.07$ & 18.07 & $0.93 \pm 0.05^{\mathrm{b} 1}$ & 15.45 \\
\hline AF 800 & $0.55 \pm 0.02^{\mathrm{a} 2}$ & 33.74 & $0.76 \pm 0.03^{\mathrm{a} 2}$ & 30.90 \\
\hline Loperamide & $0.47 \pm 0.04^{\mathrm{a} 3}$ & 43.47 & $0.68 \pm 0.02^{\mathrm{a} 3}$ & 38.18 \\
\hline
\end{tabular}

effective, cheaper and safer antidiarrheal drugs has become a paramount concern to have safe and cost effective therapeutic alternatives [2, 27]. This study was aimed to evaluate the safety and effectiveness of Myrtus communis L. as antidiarrheal agent.

Hydroalcoholic solvent mixtures are generally considered to give high extraction yields, owing to their expanded polarity index [28]. In general, hydroalcoholic co-solvents such as $80 \%$ methanol seem to possess the optimum solubility characteristics for initial crude extraction. Hence, $80 \%$ methanol was used as solvent of choice in the present study for extracting the Myrtus communis L. leaf. Besides, the dry leaf powder was resubjected for fractionation with solvents of increasing polarity to get an idea about the polarity of antidiarrheal constituents of the plant.

The acute toxicity profile of the leaf extract was determined based on OECD guideline 2008:425 [18]. On this test, the $\mathrm{LD}_{50}$ was found to be $>2000 \mathrm{mg} / \mathrm{kg}$ for the $80 \mathrm{ME}$. Generally, if the $\mathrm{LD}_{50}$ value of the test chemical is more than 3 times the minimum effective dose, the substance is considered as a good candidate for further studies [29]. Since the hydroalcoholic extract had a $\mathrm{LD}_{50}$ value of more than three times of the minimum effective dose $(100 \mathrm{mg} / \mathrm{kg})$, it was taken as a good candidate for further studies. Beyond its role for dose determination, $\mathrm{LD}_{50}$ can also be used for classification of chemicals. According to WHO hazard classification systems, the $80 \mathrm{ME}$ of the leaves of Myrtus communis L. with $\mathrm{LD}_{50}>$ $2000 \mathrm{mg} / \mathrm{kg}$ is designated as 'unlikely to be hazardous' [30]. Hence, based on the safety profile of the this extract and prior absence of any toxicity data regarding the plant, further toxicity studies were not done on the solvent fractions.

Diarrhea occurs when there is an imbalance between the secretary and absorptive processes of gastrointestinal tract and/or an alteration of motility of intestinal smooth muscles [31]. The use of $\mathrm{CO}$ as diarrhea inducer has been well documented [25, 32]. When administered orally, it produces irritant laxative effect mediated by its active metabolite, ricinoleic acid released by intestinal lipases. Ricinoleic acid produces local irritation and inflammation of the intestinal mucosa, causing the release of prostaglandins that eventually 
Table 4 In vivo antidiarrheal indices of 80ME and solvent fractions of the leaves of Myrtus communis

\begin{tabular}{|c|c|c|c|c|}
\hline Dose (mg/kg) & $\begin{array}{l}\text { Delay in defecation } \\
\text { (time of onset in min, Dfreq) (\%) }\end{array}$ & $\begin{array}{l}\text { Gut meal travel distance } \\
(\text { Gmeq) (\%) }\end{array}$ & $\begin{array}{l}\text { Purging frequency in } \\
\text { number of wet stools (\%) }\end{array}$ & $\begin{array}{l}\text { In vivo antidiarrheal } \\
\text { index (ADI) }\end{array}$ \\
\hline Control & -———— & -———— & -———- & -———— \\
\hline 80ME 100 & 43.04 & 33.54 & 42.58 & 39.47 \\
\hline 80ME 200 & 89.12 & 46.12 & 62.52 & 63.58 \\
\hline 80ME 400 & 126.72 & 62.31 & 74.96 & 83.96 \\
\hline Loperamide 3 & 110.64 & 59.61 & 72.56 & 78.22 \\
\hline Control & -——- & - - - & - - - & -—- \\
\hline CF 200 & 53.84 & 27.99 & 38.46 & 38.69 \\
\hline CF 300 & 75.25 & 35.11 & 51.23 & 51.34 \\
\hline CF 400 & 89.59 & 44.86 & 58.92 & 61.87 \\
\hline Loperamide 3 & 106.85 & 60.56 & 74.31 & 78.34 \\
\hline Control & -二- & -二- & -二- & -—-- \\
\hline MF 200 & 50.48 & 21.24 & 31.07 & 32.18 \\
\hline MF 300 & 96.16 & 35.85 & 48.93 & 55.25 \\
\hline MF 400 & 124.29 & 47.54 & 62.67 & 71.81 \\
\hline Loperamide 3 & 140.63 & 61.47 & 75.56 & 86.76 \\
\hline Control & -—-—- & -—-—- & -二-二- & -———- \\
\hline AF 200 & 2.16 & 4.81 & 8.93 & 4.53 \\
\hline AF 300 & 11.54 & 12.58 & 15.60 & 13.13 \\
\hline AF 400 & 16.83 & 20.73 & 24.40 & 20.42 \\
\hline AF 800 & 94.24 & 38.61 & 53.33 & 57.89 \\
\hline loperamide & 140.63 & 61.47 & 75.56 & 86.76 \\
\hline
\end{tabular}

$80 \mathrm{ME}=80 \%$ methanol extract, $\mathrm{CF}=$ chloroform fraction, $\mathrm{MF}=$ methanol fraction, $\mathrm{AF}=$ aqueous fraction

increase gastrointestinal motility, net secretion of water and electrolytes [24, 33].

$\mathrm{CO}$ induced diarrheal model was designed to assess the potential of a test substance in its overall antidiarrheal activities. The onset of defecation, the frequency and weight of fecal outputs were determined as the main parameters. The 80ME (middle and higher doses) significantly delayed the initiation of diarrhea and reduced the number and weight of both wet and total fecal outputs with the highest effects observed at later dose. Diarrhea

Table 5 Preliminary phytochemical screening of the 80\% methanol extract and solvent fractions of the leaves of Myrtus communis L

\begin{tabular}{lllll}
\hline Constituents & \multicolumn{2}{l}{\begin{tabular}{l} 
Crude extract \\
\cline { 2 - 5 }
\end{tabular}} & \multicolumn{3}{l}{ Solvent fraction } & \\
\cline { 2 - 5 } & Chloroform & Methanol & Aqueous \\
\hline Cardiac glycosides & + & - & + & + \\
Flavonoids & + & + & + & - \\
Alkaloids & - & - & - & - \\
Saponins & + & - & + & + \\
Steroids & - & + & - & - \\
Tannins & + & + & + & + \\
Terpenoids & + & + & + & - \\
\hline
\end{tabular}

$+=$ present; $-=$ Absent is characterized by fecal urgency and incontinence [34, 35]. Substances exhibiting significant antidiarrheal activity may have a potential to retard the onset of diarrhea as observed at 200 and $400 \mathrm{mg} / \mathrm{kg}$ 80ME. Even though diarrhea has been defined over time by various scientific groups and organizations in different ways, greater emphasis is given on the consistency of stools than the frequency [35]. Therefore, determination of the percentage inhibition has been based on the reduction of frequency of wet fecal outputs as a good marker of antidiarrheal activity. Diarrhea is also presented with an increase in weight of defecation $[35,36]$. Accordingly, the $80 \mathrm{ME}$ displayed a dose-dependent reduction in weight of fecal outputs indicating the antidiarrheal potential of the 80ME in this model.

Coming to the solvent fractions, both the CF and MF (at $400 \mathrm{mg} / \mathrm{kg}$ ) produced significant effects in all parameters in this model. In addition, both of these fractions significantly decreased the frequency of wet feces and weight of both wet and total stools at $300 \mathrm{mg} / \mathrm{kg}$. Generally, these fractions had comparable antidiarrheal effects but the effects were lower than that of the 80ME. Looking at the dose dependency nature of the fractions, the $\mathrm{MF}\left(\mathrm{R}^{2}=0.994\right)$ appeared to have a steeper slope than the CF $\left(R^{2}=0.980\right)$. This might be 
attributed to qualitative and quantitative differences in bioactive constituents of these fractions. On the contrary, the aqueous fraction was devoid of any significant delay in onset of diarrhea at all tested doses. This study was in line with other studies where the CF and MF of medicinal plants reduced the frequency and weight of stools [37, 38].

Non-steroidal anti-inflammatory drugs (NSAIDs) could inhibit castor oil induced diarrhea [39]. Similarly, 80\% ethanolic extracts of Myrtus communis L. showed potent anti-inflammatory activity in a previous study [40]. This was further supported by the fact that isolated constituents from the leaves of this plant are known to suppress the biosynthesis of eicosanoids both in vivo and in vitro [41]. Certain flavonoids, tannins and terpenoids revealed antidiarrheal activities via a multitude of mechanisms [42-44]. Most of the aforementioned secondary metabolites were screened from the leaves of this plant so far [45].

The reduction of gastrointestinal motility is one of the mechanisms by which antidiarrheal agents can act [46]. It was observed that the $80 \mathrm{ME}$ significantly suppressed the propulsion of charcoal marker at all tested doses. This finding suggests that this extract has the ability to influence the peristaltic movement of intestine thereby indicating the presence of an antimotility activity. Besides, both the CF and MF had comparable antispasmodic effects with the highest effect revealed at $400 \mathrm{mg} / \mathrm{kg}$ of MF $(47.54 \%, p<0.001)$. Previous study on isolated tissue preparations demonstrated that $70 \%$ methanolic extract of Myrtus communis L.leaf possessed bronchodilator, spasmolytic and vasodilator activities [14]. Therefore, it is plausible to assume that the in vivo antimotility effect of the $80 \mathrm{ME}$ and solvent fractions could be partly ascribed to such in vitro effects. It is in line with related studies where in vitro mechanistic studies were correlated with in vivo antimotility activities [47, 48].

The third being enteropooling model was aimed to assess the secretary components of diarrhea. In this model, the 80ME extract showed significant reduction in both AVIC and AWIC at all tested doses as compared to control. Besides, both the CF and MF showed comparable percent reduction of both AVIC and AWIC at all tested doses. On the contrary, the AF was devoid of significant inhibition of intestinal fluid accumulation up to $400 \mathrm{mg} /$ $\mathrm{kg}$. Mascolo et al. reported that the active metabolite, ricinoleic acid might activate the nitric oxide pathway and induce nitric oxide $(\mathrm{NO})$ dependent gut secretion [49]. A growing body of evidence indicated that phytochemical constituents such as terpenoids [50] and flavonoids [51] are implicated in attenuation of NO synthesis. In contrast to the aqueous fraction, the significant antisecretory activities of the $80 \mathrm{ME}$ as well as the CF and
MF could probably be related to the existence and hence synergistic effects of flavonoids, tannins and terpenoids.

Generally, the ADI value indicates a measure of how much effective an extract is in treating diarrhea [25]. ADI was increased with dose suggesting the dose dependency nature of the parameter. The $80 \mathrm{ME}$ showed highest ADI value among all extracts with corresponding doses reinforcing the notion that this extract is endowed with better antidiarrheal activity compared to the solvent fractions.

Interestingly, extensive studies revealed that the leaves of Myrtus communis L. have shown promising antimicrobial activities against several diarrhea causing pathogens [52-54]. Therefore, in addition to its antimotility and antisecretory effects observed in this study, its overwhelming antimicrobial properties reinforcing a notion that Myrtus communis L. can possibly be a good candidate for diarrheas of diverse etiologies including those with infectious component.

\section{Conclusion}

This study revealed that the $80 \mathrm{ME}$ and solvent fraction of the leaves of Myrtus communis L. are endowed with a promising antidiarrheal activity. Therefore, this finding provides a scientific support for folkloric use of Myrtus communis L. as antidiarrheal agent.

\section{Acknowledgements \\ The authors thank School of Graduate Studies, Addis Ababa University for partly supporting the study. \\ We also extend our thanks to Haramaya University for granting sponsorship to the first author. \\ Funding \\ This is described in acknowledgement section. \\ Availability of data and materials \\ The data is available in public library of Addis Ababa University in a form of graduate student thesis (institutional repository).}

\section{Authors' contribution}

MS conceived, designed and conducted experiment, acquired, analyzed and interpreted data, and drafted the manuscript; EE supervised the study; WS supervised the study, and prepared the final manuscript.

\section{Competing interests}

The authors declare that they have no competing interest.

\section{Consent for publication}

All co-authors have consented for the publication of this manuscript.

\section{Ethics approval and consent to participate}

The study was approved by Ethical Review Board of School of Pharmacy, Addis Ababa University. However, no consent was needed for this study.

\section{Author details}

'School of Pharmacy, College of Health and Medical sciences, Haramaya University, Dire Dawa, Ethiopia. ${ }^{2}$ Department of Pharmacology and clinical Pharmacy, College of Health Sciences, Addis Ababa University, Addis Ababa, Ethiopia. 
Received: 3 October 2016 Accepted: 6 February 2017 Published online: 10 February 2017

\section{References}

1. Pathak K, Das RJ. Herbal medicine-a rational approach in health care system. Int J Ayurvedic Herbal Med. 2013;1:86-9.

2. Komal S, Kumar S, Rana A. Herbal approaches for diarrhea: A review. IRJP. 2013:4:31-8.

3. d'Avigdor E, Wohlmuth $H$, Asfaw Z, Awas T. The current status of knowledge of herbal medicine and medicinal plants in Fiche, Ethiopia. J Ethnobiol Ethnomed. 2014;10(1):38. doi:10.1186/1746-4269-10-38.

4. Enyew A, Asfaw Z, Kelbessa E, Nagappan R. Status of medico-cultural commercial plants at Fiche town market, Ethiopia. Int J Pharm \& H Care Res. 2013;1(4):227-36.

5. Teklehaymanot T, Giday M. Ethnobotanical study of medicinal plants used by people in Zegie Peninsula, Northwestern Ethiopia. J Ethnobiol Ethnomed. 2007:3:12.

6. Aslam S, Ganaie KA, John AQ, Dar GH. Family Myrtaceae in Kashmir Myrtus communis, L.-A new record for the shrub world of Kashmir Himalayas. Academia Arena. 2010;2:42-3.

7. Özkan AMG and Güray CG: A Mediterranean Myrtus communis L. (Myrtle), Plants and Culture: seeds of the cultural heritage of Europe, Turkey, 2009. Retrieved from http://www.uni-graz.at/ katzer/engl/Myrtcom.ht.

8. Sumbul S, Ahmad MA, Asif M, Akhtar M. Myrtus communis Linn. A review. Indian J Nat Prod Resour. 2011;2(4):395-402.

9. Tadesse M, Mesfin B. A review of selected plants used in the maintenance of health and wellness in Ethiopia. Ee-JRIF. 2010;2(1):85-102.

10. Haq F, Ahmad H, Alam M. Traditional uses of medicinal plants of Nandiar Khuwarr catchment (District Battagram), Pakistan. J Med Plants Res. 2011; 5(1):39-48.

11. Dogan Y, Ugulu I. Medicinal plants used for gastrointestinal disorders in some districts of Izmir province, Turkey. Stud Ethno-Med. 2013;7(3):149-61.

12. Hosein FM, Abbasabadi Z, Reza SA, Abdollahi M, Rahimi R. A comprehensive review of plants and their active constituents with wound healing activity in traditional Iranian medicine. Wounds. 2014;26(7):197-206.

13. Getaneh S, Girma Z. An ethnobotanical study of medicinal plants in Debre Libanos Wereda, Central Ethiopia. Afr J Plant Sci. 2014;8(7):366-79.

14. Janbaz KH, Nisa M, Saqib F, Imran I, Zia-Ul-Haq M, De Feo V. Bronchodilator, vasodilator and spasmolytic activities of methanolic extract of Myrtus communis L. J Physiol Pharmacol. 2013;64:479-84.

15. Chala A, Engidawork E and Asres K., Antidiarrheal and antispasmodic activities of essential oil of Myrtus communis L, School of Graduates, Addis Ababa University, Ethiopia (MSc. thesis), 2011 etd.aau.edu.et/bitstream/ 123456789/5697/1/26.Adugnachala.pdf.

16. Institute for Laboratory Animal Research (ILAR). Guide for the care and use of laboratory animals. Washington DC: National Academy Press; 1996.

17. National Research Council. Guide for the Care and Use of Laboratory Animals. 8th ed. Washington, DC: The National Academies Press; 2011

18. OECD. Guidelines for Testing of Chemicals: Guideline 425: Acute Oral Toxicity Paris, France. The Organization of Economic Co-operation and Development 2008. Retrieved from http://www.oecd-ilibrary.org/environment/oecdguidelines-for-the-testing-ofchemicals-section-4-health-effe.

19. Umer S, Tekewe A, Kebede N. Antidiarrhoeal and antimicrobial activity of Calpurnia aurea leaf extract. BMC Complement Altern Med. 2013;13:21.

20. Ara A, Saleh-E-in M, Ahmed N, Hashem M, Bachar SC. anti-diarrheal activity and acute toxicity of methanolic bark extract of Adenanthera pavonina LINN (fabaceae) and its elemental composition. Turk J Pharm Sci. 2013;10(2):263-71.

21. Tadesse WT, Hailu AE, Gurmu AE, Mechesso AF. Experimental assessment of antidiarrheal and antisecretory activity of $80 \%$ methanolic leaf extract of Zehneria scabra in mice. BMC Complement Altern Med. 2014;14:460. doi:10.1186/1472-6882-14-460.

22. Yasmeen M, Prabhu B, Agashikar NV. Evaluation of the antidiarrhoeal activity of the leaves of Ixora coccinea Linn. in rats. J Clin Diagn Res. 2010; 4(5):3298-303

23. Islam AM, Uddin ME, Chowdhury MA, Rahman MM, Habib MR, Rahman MA. In vivo antidiarrheal and cytotoxic potential of different fractions of Pandanus foetidus leaves. Am J Biomed Sci. 2013;5(3):208-16.

24. Robert A, Nezamis JE, Lancaster C, Hanchar AJ, Klepper MS. Enteropooling assay: a test for diarrhea produced by prostaglandins. Prostaglandins. 1976 11(5):809-28.
25. Okpo SO, Ching FP. Evaluation of the Anti-diarrhoeal activity of the aqueous extract from leaves of Pterocarpus santalinoides. Res J Pharm Bio Chem Sc. 2011;2(3):590-7.

26. Zohra SF, Meriem B, Samira S, Alsayadi-Muneer MS. Phytochemical screening and identification of some compounds from mallow. J Nat Prod Plant Resour. 2012;2(4):512-6.

27. Kumar R, Sharma RJ, Bairwa K, Roy RK, Kumar A. Pharmacological review on natural antidiarrhoel agents. Der Pharma Chemica. 2010;2(2):66-93.

28. Gupta A, Naraniwal M, Kothari V. Modern extraction methods for preparation of bioactive plant extracts. Int J Appl Nat Sci. 2012;1(1):8-26.

29. Carol A. Acute, Sub chronic and chronic Toxicology. In: CRC, editor. Handbook of Toxicology. U.S.: CRC Press; 1995. p. 51-104.

30. WHO. Hazard classification-acute LD50 values of formulated products. In: The guidebook to the registration of public health pesticides and repellents against Vectors, 1975. Retrivied from http://app.nea.gov.sg/cms/htdocs/ article.asp?pid=1211.

31. Gidudu J, Sack DA, Pina M, Hudson MJ, Kohl KS, Bishop P, et al. Diarrhea: case definition and guidelines for collection, analysis, and presentation of immunization safety data. Vaccine. 2011;29(5):1053-71.

32. Shiferie F, Shibeshi W. In vivo antidiarrheal and ex-vivo spasmolytic activities of the aqueous extract of the roots of Echinops kebericho (Asteraceae) in rodents and isolated guinea-pig ileum. Int J Pharm Pharmacol. 2013;2:110-6.

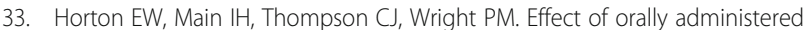
prostaglandin E1 on gastric secretion and gastrointestinal motility in man. Gut. 1968;9(6):655-8.

34. WGO. Acute diarrhea in adults and children: a global perspective, World Gastroenterology Organization Global Guidelines 2012. [Online] Available at: http://www.worldgastroenterology.org/UserFiles/file/guidelines/acutediarrhea-english-2012.pdf. Accessed 5 June 2015.

35. WHO. Diarrheal disease. 2013. [Online] Available at:http://www.who.int/ mediacentre/factsheets/fs330/en. Accessed 8 Oct 2014.

36. Thomas PD, Forbes A, Green J, Howdle P, Long R, Playford R, et al. Guidelines for the investigation of chronic diarrhoea. Gut. 2003;52 suppl 5:1-15.

37. Billah MM, Islam R, Khatun H, Parvin S, Islam E, Islam SA, Mia AA. Antibacterial, antidiarrhoeal, and cytotoxic activities of methanol extract and its fractions of Caesalpinia bonducella (L.) Roxb leaves. BMC Complement Altern Med. 2013;13:101. doi:10.1186/1472-6882-13-101.

38. Karthik P, Kumar RN, Amudha P. Antidiarrheal activity of the chloroform extract of Cayratia pedata Lam in albino wistar rats. Pharmacologyonline. 2011;2:69-75.

39. Awouters F, Niemegeers CJ, Lenaerts FM, Janssen PA. Delay of castor oil diarrhoea in rats: a new way to evaluate inhibitors of prostaglandin biosynthesis. J Pharm Pharmacol. 1978;30(1):41-5.

40. Al-Hindawi MK, Al-Deen $\mathrm{H}$, Nabi MH, Ismail MA. Anti-inflammatory activity of some Iraqi plants using intact rats. J Ethnopharmacol. 1989;26(2):163-8.

41. Feißt C, Franke L, Appendino G, Werz O. Identification of molecular targets of the oligomeric nonprenylated acylphloroglucinols from Myrtus communis and their implication as anti-inflammatory compounds. J Pharmacol Exp Ther. 2005;315(1):389-96.

42. Galvez J, Crespo ME, Jimenez J, Suarez A, Zarzuelo A. Antidiarrhoeic activity of quercitrin in mice and rats. J Pharm Pharmacol. 1993;45(2):157-9.

43. Ren A, Zhang W, Thomas HG, Barish A, Berry S, Kiel JS, et al. A tannic acidbased medical food, Cesinex ${ }^{\circledast}$, exhibits broad-spectrum antidiarrheal properties: a mechanistic and clinical study. Dig Dis Sci. 2012;57(1):99-108.

44. Jalilzadeh-Amin G, Maham M. The application of 1, 8-cineole, a terpenoid oxide present in medicinal plants, inhibits castor oil-induced diarrhea in rats. Pharm Biol. 2015;53(4):594-9.

45. Al-Hajjar MA, Al-Shahiry KF, Al-Abache SM. Isolation and Identification of some active constituents of Myrtus Communis in Iraq by using HPLC, FTIR techniques. Irq Nat J Chem. 2012;45:11-22.

46. Schiller LR, Santana CA, Morawski SG, Fordtran JS. Mechanism of the antidiarrheal effect of loperamide. Gastroenterology. 1984;86(6):1475-80.

47. Mehmood MH, Siddiqi HS, Gilani AH. The antidiarrheal and spasmolytic activities of Phyllanthus emblica are mediated through dual blockade of muscarinic receptors and $\mathrm{Ca}^{2+}$ channels. J Ethnopharmacol. 2011;133(2): 856-65.

48. Shah AJ, Bhulani NN, Khan SH, Gilani AH. Calcium channel blocking activity of Mentha longifolia L. explains its medicinal use in diarrhoea and gut spasm. Phytother Res. 2010;24(9):1392-7.

49. Mascolo N, Izzo AA, Autore G, Barbato F, Capasso F. Nitric oxide and castor oil-induced diarrhea. J Pharmacol Exp Ther. 1994;268(1):291-5. 
50. Jang DS, Min HY, Jeong YH, Lee SK, Seo EK. Di-and sesqui-terpenoids isolated from the pods of Sindora sumatrana and their potential to inhibit lipopolysaccharide-induced nitric oxide production. Arch pharmacal res. 2004:27(3):291-4.

51. Messaoudene D, Belguendouz H, Ahmedi ML, Benabdekader T, Otmani F, Terahi $M$, et al. Ex vivo effects of flavonoïds extracted from Artemisia herba alba on cytokines and nitric oxide production in Algerian patients with Adamantiades-Behçet's disease. J Inflamm. 2011;8(1):1. doi:10.1186/14769255-8-1.

52. Alem $G$, Mekonnen $Y$, Tiruneh M, Mulu A. Invitro antibacterial activity of crude preparation of myrtle (Myrtus communis) on common human pathogens. Ethiop Med J. 2008;46(1):63-9.

53. Appendino G, Maxia L, Bettoni P, Locatelli M, Valdivia C, Ballero M, et al. Antibacterial Galloylated Alkylphloroglucinol Glucosides from Myrtle (Myrtus communis). J Nat Prod. 2006:69(2):251-4.

54. Sulaiman GM, Abdulwahed HE, Abdulwahed AL, Mohammad AA. Antimicrobial activity of silver nanoparticles synthesized by Myrtus communis extract. Eng Technol J. 2013;31:400-9.

Submit your next manuscript to BioMed Central and we will help you at every step:

- We accept pre-submission inquiries

- Our selector tool helps you to find the most relevant journal

- We provide round the clock customer support

- Convenient online submission

- Thorough peer review

- Inclusion in PubMed and all major indexing services

- Maximum visibility for your research

Submit your manuscript at www.biomedcentral.com/submit
Biomed Central 